\title{
SEISMIC ANALYSIS OF MULTISTOREY BUILDING WITH BARE FRAME, BARE FRAME WITH SLAB ELEMENT AND SOFT STOREY AT DIFFERENT LEVELS OF THE BUILDING FOR SEISIMIC ZONE II
}

\author{
D.Nagaraju ${ }^{1}$, K.Lakshmaiah ${ }^{2}$, B Manoj Yadav ${ }^{3}$ \\ ${ }^{1}$ Assistant Professor, Department of Civil Engineering, QIS College of Engineering \& Technology, Ongole \\ ${ }^{2}$ Assistant Professor, Department of Civil Engineering, QIS College of Engineering \& Technology, Ongole \\ ${ }^{3}$ Professor, Department of Civil Engineering, QIS College of Engineering \& Technology, Ongole
}

\begin{abstract}
Masonry infill panels are generally examined as non-structural elements and their stiffness contributions are generally ignored in practice, such an approach can lead to a vulnerable model. In the soft storey, the inter storey drifts and seismic demands of the columns are excessive that causes heavy damage or collapse of the buildings during a severe earthquake. In modeling, the Finite Element Method is formerly used and the ETABS software is employed for the linear dynamic analysis of all the different models. This paper discussed about the storey drifts, lateral displacements and base shears of six models including bare frame and bare frame with slab element in seismic zone II. Also this study has been carried out to compare modified first soft storey, second soft storey, and third soft storey provisions with complete infill wall frame, bare frame models, and bare frame with slab element. Results shows a general changing pattern in storey drifts, lateral displacements and base shear irrespective to building height and maximum inter-storey drift was obtained where the soft storey was located at different levels of the building.
\end{abstract}

\section{INTRODUCTION}

A large number of buildings with soft storey at various levels have been built in India in recent year. But it showed poor rendering during past earthquakes. Therefore it is need of time to take immediate steps to prevent the indiscriminate use of soft first storeys in buildings, the increased displacements and force demands in soft storey at different levels of the building. In this regard, this paper discussed about the storey drifts, lateral displacements and base shears of six models including bare frame and bare frame with slab element at different levels in seismic zone II.

\subsection{Prediction of Soft Storey's}

Soft storey RC frame buildings are commonly analyzed and designed as bare frames, bare frame with slab element, full wall element, open first soft storey, second soft storey, and third soft storey in zone II. However actual behavior of bare frames is entirely different from that of the other Models. In soft storey buildings, ground storey is bare and upper stories of the building are infilled with masonry. Therefore, it is of interest to analyze and compare displacement, drifts, base shear etc. of the same frame, modeling it as bare frame and as soft storey frame. Such comparison will be useful to understand how the performance of soft storey RC frame is different from that of the other Models. In this paper seismic zone analysis have been performed to study the behavior of multistoried RC frame building with six different Models in seismic zone II by linear dynamic analysis according to IS 1893 (Part 1): 2002 using commercial software ETABS 9.7.

\section{OBJECTIVES}

Following are some objectives:-

1. The main objective of this dissertation is focus on the behavior of RC frame buildings with bare frame, bare frame with slab element, first soft storey, second soft storey, third soft storey in seismic zones II.

2. To study the effect of storey drifts, lateral displacement \& base shear in the seismic zones II of bare frame, bare frame with slab element, full infills, and soft storey at different levels of buildings.

3. To check the necessity of the multiplication factor of 2.5 as given by the Indian Standard IS 1893:2002 for design of bare frame, bare frame with slab element, full infill's, and soft storey at different levels of building in zones II.

4. To analyze the RC frame for dynamic analysis in relation to the storey drift and lateral displacements, base shear using software ETABS.

5. To study the comparison between the storey drifts, lateral displacements, base shear of all Models in seismic zones II.

6. To investigate the bare frame, soft storey behavior at different levels of RC frame building for all cases so as to arrive at suitable practical conclusion for achieving earthquake resistant RC frame building.

7. To identify the storey drift where there is exceeds its permissible values of storey drifts i.e.0.004h, in zone II for different Models.

8. To study failure conditions of six Models at different Storey's in zone II for all Model buildings.

9. To promote safety without too much changing the constructional practice of reinforced concrete structures. 


\section{INTRODUCTION TO ETABS}

ETABS is objecting based, meaning that the Models are created with members that represent physical reality. Results for analysis and design are reported for the overall object, providing information that is both easier to interprets and consistent with physical nature. The ETABS structural analysis programmer offers following features-

- Static and Dynamic Analysis

- Linear and Nonlinear Analysis

- Dynamic seismic zone analysis and Static push over analysis

- Geometric Nonlinearity including P- $\Delta$ effect

- Frame and shell structural elements

- 2-D and 3-D plane and solid elements

\subsection{Building Description}

The Modeling of the G+10 storey with bare frame, bare frame with slab element, full wall element structure, first soft storey, two storey soft storey ,three Storey's soft storey. Plan area of building is $32 \mathrm{~m} \times 21 \mathrm{~m}$, the building Models having 4 bays at $8 \mathrm{~m}$ distance in $\mathrm{x}$-direction and 3 bays at $7 \mathrm{~m}$ distance in $\mathrm{y}$ - direction.

Model 1: Bare frame

Model 2: Bare frame with slab element.

Model 3: Building has full walls with external walls (230mm thick) and internal walls $(115 \mathrm{~mm}$ thick) in all stories have and slab element.

Model 4: Building has first soft storey with external walls (230mm thick) and internal walls (115mm thick) and slab element.

Model 5: Building has two soft storey with external walls (230mm thick) and internal walls $(115 \mathrm{~mm}$ thick) and slab element.

Model 6: Building has three storey soft storey with external walls (230mm thick) and internal walls $(115 \mathrm{~mm}$ thick) and slab element.

\subsection{Analyzing the data}

Linear dynamic analysis has been performed as per IS 1893 (Part 1): 2002 for each model using ETABS analysis package. Lateral load calculation and its distribution along the height are done. The seismic weight is calculated using $100 \%$ of dead load plus $25 \%$ of live load.

Following data is used in the analysis of the RC frame building Models

Table 3.1: Data relation to the RC frame building Models

\begin{tabular}{|l|l|}
\hline Type of frame & $\begin{array}{l}\text { Ordinary Moment } \\
\text { Resisting RC Frame } \\
\text { OMRF fixed at the } \\
\text { base }\end{array}$ \\
\hline Seismic zone & II \\
\hline Number of storey & G+10 storey \\
\hline Floor height & $3 \mathrm{~m}$ \\
\hline Slab depth & $150 \mathrm{~mm}$ \\
\hline Beam size & $(230 \times 600) \mathrm{mm}$ \\
\hline Size of column & $(230 \times 750) \mathrm{mm}$ \\
\hline
\end{tabular}

\begin{tabular}{|c|c|}
\hline $\begin{array}{l}\text { Spacing between frames in } \mathrm{x} \text { - } \\
\text { direction }\end{array}$ & $8 \mathrm{~m}$ \\
\hline $\begin{array}{l}\text { Spacing between frames in } y- \\
\text { direction }\end{array}$ & $7 \mathrm{~m}$ \\
\hline Materials & $\begin{array}{l}\text { M } 25 \text { concrete, Fe } 415 \\
\text { steel and }\end{array}$ \\
\hline Infill & Brick \\
\hline $\begin{array}{l}\text { Thickness of external infill } \\
\text { walls }\end{array}$ & $230 \mathrm{~mm}$ \\
\hline $\begin{array}{l}\text { Thickness of external infill } \\
\text { walls }\end{array}$ & $115 \mathrm{~mm}$ \\
\hline Density of concrete & $24 \mathrm{KN} / \mathrm{m}^{3}$ \\
\hline Density of infill & $20 \mathrm{KN} / \mathrm{m}^{3}$ \\
\hline Soil type & Medium soil \\
\hline Seismic zone & As per IS (1893-2002) \\
\hline Seismic zone factor, $\mathrm{Z}$ & For zone II: 0.10 \\
\hline Importance Factor, I & 1 \\
\hline Response spectrum analysis & $\begin{array}{ll}\text { Linear } & \text { dynamic } \\
\text { analysis } & \end{array}$ \\
\hline Damping of structure & 5 percent \\
\hline $\begin{array}{l}\text { Plinth height above ground } \\
\text { level }\end{array}$ & $1.8 \mathrm{~m}$ \\
\hline Type of the building & $\begin{array}{l}\text { OMRF(Ordinary } \\
\text { moment resisting RC } \\
\text { frame ) }\end{array}$ \\
\hline $\begin{array}{l}\text { Wall load for the outer side } \\
\text { for ( } 3 \mathrm{~m} \text { height wall) }\end{array}$ & $12.42 \mathrm{KN} / \mathrm{m}$ \\
\hline $\begin{array}{l}\text { Wall load for the inner side } \\
\text { for ( } 3 \mathrm{~m} \text { height wall) }\end{array}$ & $6.21 \mathrm{KN} / \mathrm{m}$ \\
\hline $\begin{array}{l}\text { Wall load for the outer side } \\
\text { for ( } 1.8 \mathrm{~m} \text { height wall) }\end{array}$ & $6.90 \mathrm{KN} / \mathrm{m}$ \\
\hline $\begin{array}{l}\text { Wall load for the inner side } \\
\text { for ( } 1.8 \mathrm{~m} \text { height wall) }\end{array}$ & $3.45 \mathrm{KN} / \mathrm{m}$ \\
\hline Total Dead load of slab & $5.75 \mathrm{KN} / \mathrm{m}^{2}$ \\
\hline Live load & $2 \mathrm{KN} / \mathrm{m}^{2}$ \\
\hline
\end{tabular}

\subsection{Materials used}

\subsubsection{Concrete}

The following properties are considered for concrete taken under study.

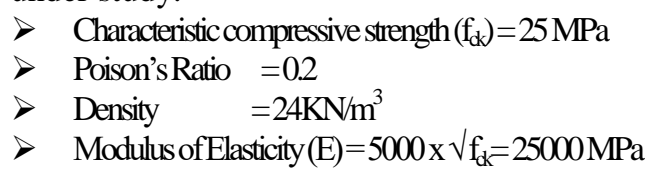

\subsubsection{Steel}

The following properties are considered for steel taken under study.
$>$ Yield Stress $\left(\mathrm{f}_{\mathrm{y}}\right)$
$>$ Modulus of Elasticity $(\mathrm{E}) \quad=2 \times 10^{5} \mathrm{MPa}$ 


\subsubsection{Masonry infill}

Clay burnt brick, Class A, confined unreinforced masonry

Compressive strength of Brick, $\mathrm{f}_{\mathrm{m}} \quad=10 \mathrm{MPa}$

Modulus of Elasticity of masonry $\left(\mathrm{E}_{\mathrm{j}}\right)=550 \mathrm{xf}_{\mathrm{m}}=5500 \mathrm{MPa}$

Poisons Ratio $=0.15$

\subsection{Load calculations}

1. Gravity loading: (As per IS: 456 - 2000 \& IS: 875 (Part II)-1987) For Dead Load (DL) Intensity of external wall (for $3 \mathrm{~m}$ height $)=12.42 \mathrm{KN} / \mathrm{m}$

Intensity of internal wall (for $3 \mathrm{~m}$ height) $\quad=6.21 \mathrm{KN} / \mathrm{m}$ Intensity of external wall $(1.8 \mathrm{~m}$ height $) \quad=6.90 \mathrm{KN} / \mathrm{m}$ Intensity of internal wall $(1.8 \mathrm{~m}$ height $) \quad=3.45 \mathrm{KN} / \mathrm{m}$ Intensity of slab load Intensity of floor finish load Intensity of roof treatment load Intensity of live load (LL) $=2 \mathrm{KN} / \mathrm{m}^{2}$.$$
=3.75 \mathrm{KN} / \mathrm{m}^{2}
$$$$
=1 \mathrm{KN} / \mathrm{m}^{2}
$$$$
=1.5 \mathrm{KN} / \mathrm{m}^{2}
$$

2. Lateral loading: (as per IS1893-2002) Lateral loading consists of earthquake loading. Earthquake loading has been calculated directly by the software and it has been applied to the center of mass of the building. Since the building under consideration was in Zones II with standard occupancy so the result was evaluated for the worst condition of load combination i.e. (0.9DL+1.5EQX) by Code. The Response reduction factor, $\mathrm{R}=3$ for OMRF (Ordinary moment resisting $\mathrm{RC}$ frame). Importance factor, $\mathrm{I}=1$, Soil Type $=\mathrm{II}$ (Medium Soil), Seismic zone factor, $Z=0.10$ for zone II.

3. Load combination: the multistorey building under study was in Zones II with standard occupancy as per standards so the result was computed for the worst condition of load combination have been taken i.e. $(0.9 \mathrm{DL}+1.5 \mathrm{EQX})$ by Code.

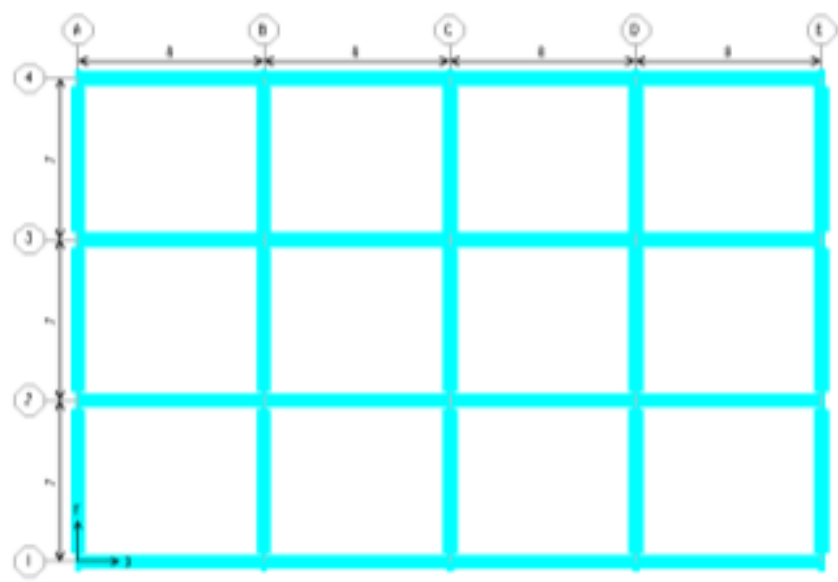

Fig 3.1: Plan for $\mathrm{G}+10$ storey building

\subsection{RC Frame Building Models considered in the}

\section{Thesis}

1) Model 1: Bare frame

2) Model 2: Bare frame with slab element.
3) Model 3: Building has full walls with external walls (230mm thick) and internal walls (115mm thick).

4) Model 4: Building has first soft storey with external walls (230mm thick) and internal walls (115mm thick).

5) Model 5: Building has two stories soft storey with external walls $(230 \mathrm{~mm}$ thick) and internal walls (115mm thick) from ground level.

6) Model 6: Building has three stories soft storey with external walls $(230 \mathrm{~mm}$ thick) and internal walls (115mm thick) from ground level

\section{Prepared Models}
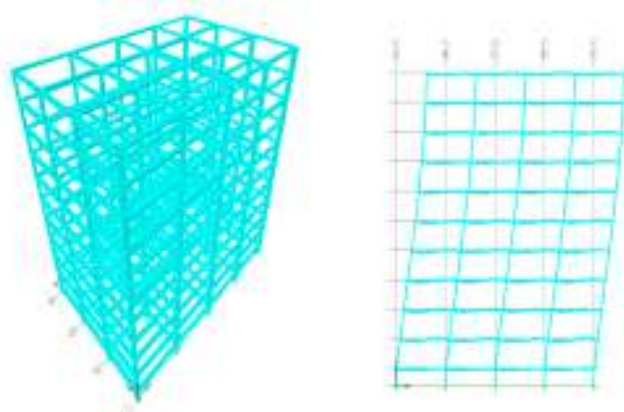

a) 3D view $\quad$ b) Lateral displacement

Fig 3.2: Model 1: G+10 RC bare frame building

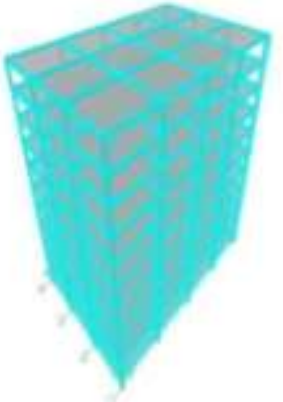

a) $3 \mathrm{D}$ view

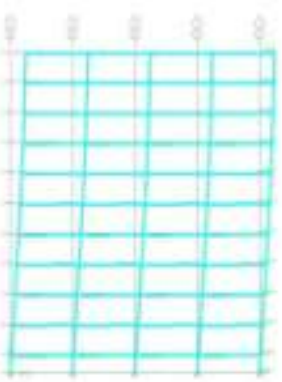

b) Lateral displacement
Fig 3.3: Model2: G+10 RC bare frame building with slab element

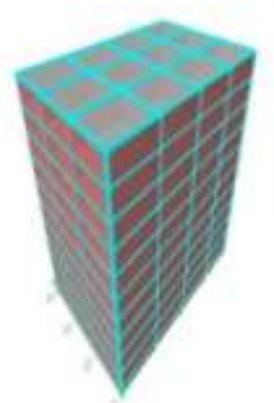

a) $3 \mathrm{D}$ view

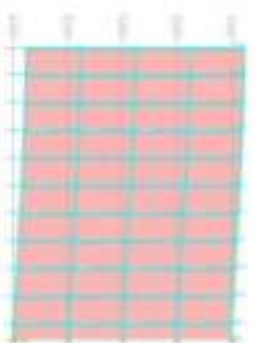

b) Lateral displacement
Fig 3.4: Model 3: G+10 RC building of full infill wall with slab element 


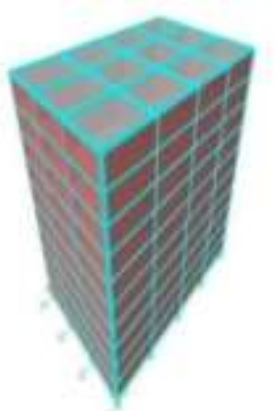

a)3D view

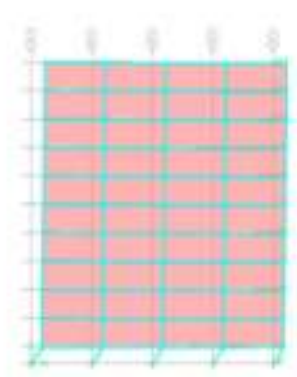

b) Lateral displacement

Fig 3.5: Model 4: G+10 RC first soft storey building with slab element
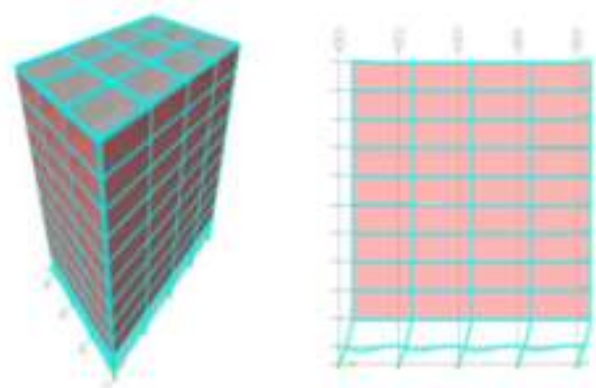

a) $3 \mathrm{D}$ view

b) Lateral displacement

Fig 3.6: Model5: G+10 RC two soft storey building with slab element
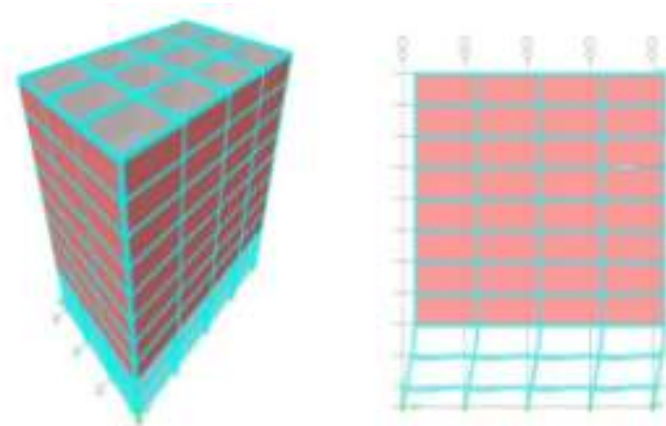

a) $3 \mathrm{D}$ view b) Lateral displacement

Fig 3.7: Model6: G+10 RC three soft storey building with slab element

\section{CHAPTER}

\subsection{Results and Discussions}

Case 1: Seismic Zone II

Table 4.1: Comparison of Storey Drifts $(\mathrm{mm})$ of all building Models in seismic zone II at all storey levels

\begin{tabular}{|l|l|l|l|l|l|l|}
\hline Storey No. & Model 1 & Model 2 & Model 3 & Model 4 & Model 5 & Model 6 \\
\hline Storey 1 & 3.500 & $\mathbf{3 . 7 3 0}$ & 1.240 & $\mathbf{5 . 2 7 0}$ & $\mathbf{6 . 8 8 0}$ & $\mathbf{7 . 8 3 0}$ \\
\hline Storey 2 & 7.720 & 3.370 & 2.940 & 0.150 & 4.010 & 5.930 \\
\hline Storey 3 & $\mathbf{8 . 7 2 0}$ & 3.240 & $\mathbf{3 . 3 2 0}$ & 0.100 & 0.080 & 1.880 \\
\hline Storey 4 & 8.880 & 3.160 & 3.310 & 0.120 & 0.050 & 1.070 \\
\hline Storey 5 & 8.660 & 3.060 & 3.210 & 0.110 & 0.060 & 1.040 \\
\hline Storey 6 & 8.220 & 2.900 & 3.050 & 0.110 & 0.050 & 1.040 \\
\hline Storey 7 & 7.550 & 2.660 & 2.790 & 0.110 & 0.050 & 1.040 \\
\hline Storey 8 & 6.650 & 2.340 & 2.450 & 0.100 & 0.050 & 1.040 \\
\hline Storey 9 & 5.590 & 1.930 & 1.990 & 0.090 & 0.040 & 1.030 \\
\hline Storey 10 & 4.970 & 1.420 & 1.410 & 0.070 & 0.040 & 1.030 \\
\hline Storey 11 & 5.800 & 0.870 & 0.800 & 0.080 & 0.050 & 1.040 \\
\hline
\end{tabular}

\subsection{Maximum Storey Drifts of all Building Models at}

\section{different Storey Levels in Seismic Zone II}

The storey drift in any storey should not exceed 0.004 times the height of storey height, Height of Storey $=0.004(\mathrm{~h})=$ $0.004(3000)=12 \mathrm{~mm}$.
Table 4.2: Comparision of Maximum storey drifts in Each building Model for zone II

\begin{tabular}{|l|l|l|l|}
\hline & $\begin{array}{l}\text { Maximum } \\
\text { storey } \\
\text { drifts(mm) }\end{array}$ & Storey No. & $\begin{array}{l}\text { Permissible } \\
\text { drift(mm) }\end{array}$ \\
\hline Model 1 & 8.88 & storey 4 & 12 \\
\hline Model 2 & 3.73 & storey 1 & 12 \\
\hline Model 3 & 3.32 & storey 3 & 12 \\
\hline Model 4 & 5.27 & storey 1 & 12 \\
\hline Model 5 & 6.88 & storey 1 & 12 \\
\hline Model 6 & 7.83 & storey 1 & 12 \\
\hline
\end{tabular}




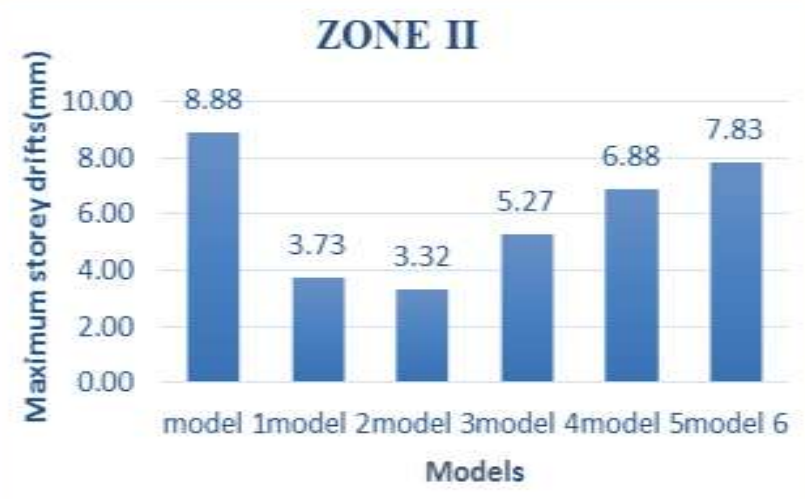

Fig 4.1: Maximum storey drifts (mm) for all building Models in zone II

Design Seismic Base Shear $\left(\mathbf{V}_{\mathbf{b}}\right)$ : the total design lateral force which is acting at the base of a structure called as design seismic base shear. Hence after analyzing the building the results obtained for six Models in zone II for load combination of $(0.9 \mathrm{DL}+1.5 \mathrm{EQX})$ and there comparisons are presented in tabular Form.

\subsection{Base Shear in all Building Models for Seismic}

Zone II

Base shear is calculated by using IS 1893-2002 method for all six models in Tables and Figures; illustrate the comparison of base shear using linear dynamic analysis. Base shear is a very important parameter for design of earthquake resistant buildings.

Table: 4.3 Comparison of base shear of all building Models for seismic zone II

\begin{tabular}{|l|l|l|l|l|l|l|}
\hline \multicolumn{7}{|l}{ Zone II } \\
Base Shear(KN) & Model 1 & Model 2 & Model 3 & Model 4 & Model 5 & Model 6 \\
\hline Height of buildings(m) & -19.48 & -74.3 & -325.14 & -140.27 & -103.89 & -102.29 \\
\hline 31.8 & -19.48 & -74.3 & -325.14 & -140.27 & -103.89 & -102.29 \\
\hline 28.8 & -37.8 & -137.56 & -670.54 & -289.29 & -214.25 & -210.95 \\
\hline 28.8 & -37.8 & -137.56 & -670.54 & -289.29 & -214.25 & -210.95 \\
\hline 25.8 & -52.51 & -188.33 & -947.73 & -408.88 & -302.81 & -298.16 \\
\hline 25.8 & -52.51 & -188.33 & -947.73 & -408.88 & -302.81 & -298.16 \\
\hline 22.8 & -63.99 & -227.98 & -1164.21 & -502.27 & -371.98 & -366.26 \\
\hline 22.8 & -63.99 & -227.98 & -1164.21 & -502.27 & -371.98 & -366.26 \\
\hline 19.8 & -72.74 & -257.88 & -1327.46 & -572.7 & -424.14 & -417.62 \\
\hline 19.8 & -72.74 & -257.88 & -1327.46 & -572.7 & -424.14 & -417.62 \\
\hline 16.8 & -79.05 & -279.4 & -1444.99 & -623.41 & -461.7 & -454.6 \\
\hline 16.8 & -79.05 & -279.4 & -1444.99 & -623.41 & -461.7 & -454.6 \\
\hline 13.8 & -83.25 & -293.93 & -1524.3 & -657.62 & -487.04 & -479.55 \\
\hline 13.8 & -83.25 & -293.93 & -1524.3 & -657.62 & -487.04 & -479.55 \\
\hline 10.8 & -85.83 & -302.82 & -1572.87 & -678.58 & -502.56 & -494.83 \\
\hline 10.8 & -85.83 & -302.82 & -1572.87 & -678.58 & -502.56 & -494.83 \\
\hline 7.8 & -87.17 & -307.46 & -1598.21 & -689.51 & -510.65 & -501.16 \\
\hline 7.8 & -87.17 & -307.46 & -1598.21 & -689.51 & -510.65 & -501.16 \\
\hline 4.8 & -87.68 & -309.22 & -1607.8 & -692.79 & -513.72 & -502.93 \\
\hline 4.8 & -87.68 & -309.22 & -1607.8 & -692.79 & -513.72 & -502.93 \\
\hline 1.8 & -87.75 & -309.46 & -1608.86 & -693.13 & -514.11 & -503.17 \\
\hline 1.8 & -87.75 & -309.46 & -1608.86 & -693.13 & -514.11 & -503.17 \\
\hline 0 & & & & & & \\
\hline
\end{tabular}




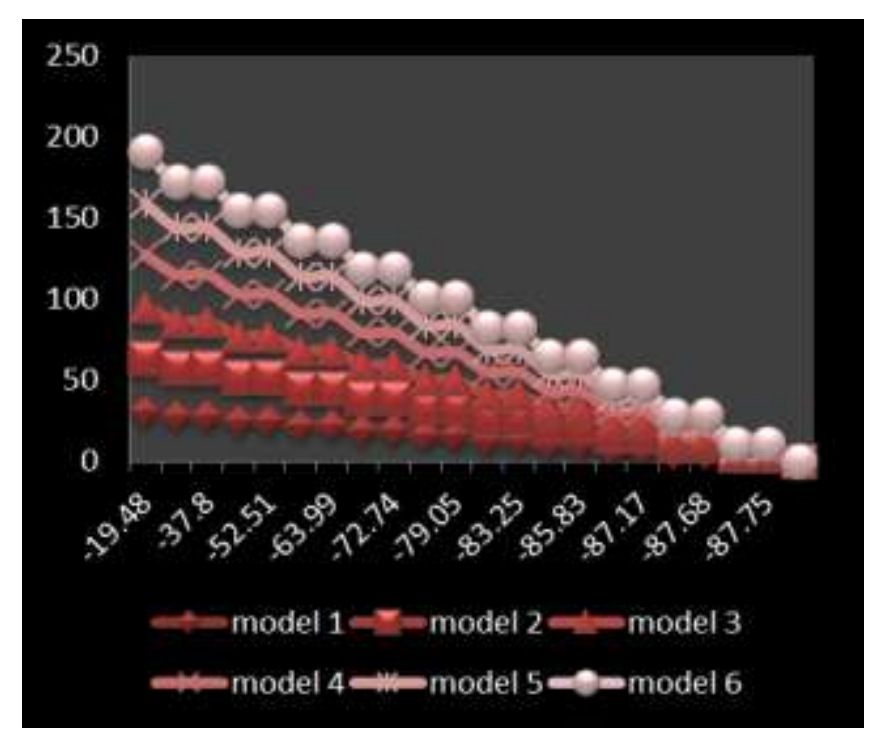

Fig4.2: Comparison of base shear (KN) in all building models for seismic zone II

\section{CHAPTER}

\subsection{Summary}

Linear Dynamic Analysis has been performed on six types of RC building Models such as R.C bare frame, R.C bare frame with slab element, R.C building with first soft storey, R.C building with second soft storey and R.C building with third soft storey from ground level of the building in zones II as per IS 1893: 2002.

\subsection{Conclusion}

The IS code methods describing very insufficient guidelines about infill wall design methodologies adopted. ETABS Software is used as a tool for analyzing the impact of infill on the structural behavior. It is observed that it provides overestimated limits of storey drift, lateral displacement and base shear. According to relative values of all limitations, it can be concluded that provision of infill wall increases the concert in terms of displacement, storey drift \& lateral stiffness.

- The storey drifts observed of the structure are found within the limit as specified by code (IS: 1893-2002, part-1) in linear dynamic analysis.

- Storey drift value is more in the storey 11 of bare frame as compared to the soft storey at different levels of building.

- The presence of masonry infill wall influences the overall behavior of structures when subjected to lateral forces. Lateral displacements and storey drifts are considerably reduced while contribution of the infill brick wall is taken into account.

- Lateral displacement of bare frame Model is higher than other Models because of less lateral stiffness of storey, due to absence of infill walls. The lateral displacements were observed in model 2 are reduced to $13.14 \%$, $20.68 \% 30.74 \%$ and $45.82 \%$ as compared to the model 1 in zone II respectively

- First storey displacement of soft first storey Model is maximum than other Models due to subbatical of infill in the first storey. In soft first storey frame, there is sudden change in drifts between first and second storey in all seismic zones.

- Concluded that the providing of infill wall in RC building guides the displacement, storey drifts and lateral stiffness.

- The increase in base shear in models III, IV and V was $71.64 \%, 94.54 \%, 87.34 \%, 82.93 \%$, and $82.56 \%$ respectively when compared to the model 1 in zone II.

- Base shear is more in full infilled Model (model 3) as compared to the other R.C building models.

- Bare frame has a lesser value of base shear as compared to the other R.C building Models.

\section{SCOPE OF WORK}

Soft storey is a distinctive feature in the current multistorey constructions in urban India. Such constituents are highly undesirable in buildings built in active seismic areas. In normal practice, only the load due to masonry infill were considered, and do not consider the composite action. It will be interesting if the comparison made between the storey drifts, lateral displacement and base shear in zones II.

\section{REFERENCES}

[1] C.V.R.Murty, "Why Are Open Ground Storey Buildings Vulnerable in Earthquakes", Indian Institute of Technology Kanpur, Earthquake tip 21, December 2003.

[2] Dhadde Santosh (2014), Evaluation and Strengthening of Soft Storey Building, International Journal of Ethics in Engineering \& Management Education.

[3] ETABS (Version 9.7) “ETABS User's Manual Revision 9.7"

[4] F. Demir and M. Sivri "Earthquake Response of Masonry Infilled Frames" ECAS2002 International Symposium on Structural and Earthquake Engineering, October 14, 2002, Middle East Technical University, Ankara, Turkey 